\title{
PENGEKPLOITASIAN TANAH ULAYAT BERBASIS SISTEM EKONOMI KERAKYATAN YANG BERKEADILAN SOSIAL DAN BERKESINAMBUNGAN
}

\author{
Zulheri Rajo Intan
}

\author{
* Dosen Fakultas Hukum Universitas Andalas, Padang \\ Korespondensi: zulheri@gmail.com \\ Naskah dikirim: 21 April 2016 \\ Naskah diterima untuk diterbitkan: 28 Mei 2016
}

\begin{abstract}
This article aims to visualize a concept for an appropriate exploitation of tanah ulayat (lands traditionally owned by local community/LTOBLC). This concept would reform the use of LTOBLC to welfare the local society. To envision this idea, this research identified the problems that the lack of scheme for managing the LTOBLC and misconception the principle of social justice as mentioned at the fifth Sila of Pancasila has disabled the local community to come out from the long-term structured poverty since the Dutch colonialism until now. Therefore, this research offers a new scheme dealing with the use of LTOBLC that required resolving the problems mentioned above. This scheme could be embodied through a mutual symbiosis between the local community and the company. However, this dramatically step would change the existing management of LTOBLC from PIR to plasma. To achieve a workable concept of the use of LTBOLC, it is necessary to introduce a new scheme of exploitation based on the concept of social justice and its sustainability. To realize such proposal, I would argue that revitalization 100\%. This work concludes that the appropriate concept on the use of LTBOLC is required to correct such deficiency mentioned above to promote a fair and sustainable exploitation of the LTBOLC for a welfare local community.
\end{abstract}

Keywords: communal land, exploitation, a democratic economic system, social justice, prosperity, safety

\begin{abstract}
Abstrak
Artikel ini bertujuan untuk memvisualisasikan konsep untuk eksploitasi sesuai tanah ulayat (tanah tradisional milik masyarakat setempat). Konsep ini akan mereformasi penggunaan tanah tradisional milik masyarakat setempat untuk kesejahteraan masyarakat setempat. Untuk membayangkan ide ini, penelitian ini mengidentifikasi masalah bahwa kurangnya skema untuk mengelola tanah tradisional milik masyarakat setempat dan kesalahpahaman prinsip keadilan sosial seperti yang disebutkan di Sila Kelima Pancasila telah dinonaktifkan masyarakat setempat untuk keluar dari kemiskinan jangka panjang terstruktur
\end{abstract}


sejak penjajahan Belanda sampai sekarang. Oleh karena itu, penelitian ini menawarkan skema baru berurusan dengan penggunaan tanah tradisional milik masyarakat setempat yang diperlukan untuk menyelesaikan masalah di atas. Skema ini dapat diwujudkan melalui simbiosis bersama antara masyarakat lokal dan perusahaan. Namun, ini secara dramatis akan mengubah langkah manajemen yang ada dari tanah tradisional milik masyarakat setempat dari PIR ke plasma. Untuk mencapai konsep yang bisa diterapkan penggunaan tanah tradisional milik masyarakat setempat, perlu untuk memperkenalkan skema baru eksploitasi berdasarkan konsep keadilan sosial dan keberlanjutan. Untuk mewujudkan usulan tersebut, saya berpendapat revitalisasi yang 100\%. Karya ini menyimpulkan bahwa konsep yang sesuai pada penggunaan tanah tradisional milik masyarakat setempat diperlukan untuk memperbaiki kekurangan tersebut disebutkan di atas untuk mempromosikan eksploitasi yang adil dan berkelanjutan dari tanah tradisional milik masyarakat setempat bagi kesejahteraan komunitas lokal.

Kata kunci: tanah komunal, eksploitasi, sistem ekonomi yang demokratis, keadilan sosial, kemakmuran, keamanan

\section{Latar Belakang Permasalahan}

Secara fenomenal, pemanfaatan tanah ulayat (TU), sejak Verenigde Oostindische Compagnie/VOC - Belanda hingga masa kemerdekaan sekarang, terbukti tidak menciptakan ekonomi kerakyatan yang berkeadilan dan berkesinambungan demi mewujudkan kesejahteraan dan kemakmuran rakyat. Secara kontroversial, pengekploitasian atau pemanfaatan TU bukan mensejahterakan rakyat, melainkan menyengsarakan rakyat. Hal ini terlihat dari lebih 4000 konflik pertanahan yang belum terselesaikan hingga kini, yang lebih separuhnya merupakan konflik antar keluarga atau antar masyarakat lokal (konflik horizontal), sedangkan sisanya konflik antar masyarakat dan perusahaan (konflik vertikal). Diantara Konflik tersebut termasuk konflik TU yang angka pastinya memerlukan penulisan tersendiri. Dari berbagai konflik TU itu, rakyat (masyarakat lokal) sebagai pihak yang lemah cendrung dimarjinalkan, ditekan, dikalahkan bahkan dirugikan. Selain menyita waktu yang terbuang percuma, penyelesaian konflik itu juga telah menghabiskan dana yang cukup besar, menimbulkan korban jiwa dan harta. Dari banyak kasus tersebut boleh dikatakan bahwa pemanfaatan tanah ulayat di Indonesia belum memberikan kesejahteraan kepada rakyat, khususnya kepada masyarakat lokal.

Munculnya permasalahan tersebut di atas disebabkan oleh beberapa fakor pemicu antara lain: 1) kerancuan dalam pengertian tanah ulayat itu sendiri; 2) belum adanya cetak biru (blue print) pengekploitasian tanah ulayat; 3) masih tidak jelasnya konsepsi ekonomi kerakyatan sebagaimana disebutkan pasal 33 Konstitusi RI dan kaitannya dengan pemanfaatan TU; 4) belum adanya konsep pemanfaatan TU berbasis keadilan sosial dan yang berkesinambungan; 5) terjadinya pengkonversian TU menjadi hak-hak lainnya, seperti hak milik, tanah negara; 6) tidak adanya kebijakan publik (pemerintah) baik pusat 
maupun daerah untuk membuat panduan (peraturan) pemanfaatan TU untuk kesejahteraan rakyat, dan 7) tidak adanya keberpihakan pemerintah kepada rakyat sebagaimana terlihat pada berbagai perarturan perundangan, seperti UU investasi, serta 8) rendahnya pemahaman (pendidikan) masyarakat, khususnya mengenai pertanahan (TU).

Inti permasalahannya dapat diperhatikan pada pengaturan tanah ulayat itu sendiri. Permasalahannya, pengaturan TU belum sistematis dan tidak koheren (tidak sinkron) dengan peraturan nasional lainnya. Secara individual, pengaturan TU dapat ditemukan pada Peraturan Menteri Agraria/Kepala Badan Pertanahan Nasional No. 5 Tahun 1999 tentang Pedoman Penyelesaian Masalah Hak Ulayat Masyarakat Hukum Adat (Permeneg Agraria), Peraturan Daerah Sumatera Barat Nomor 2008 tentang Tanah Ulayat dan Pemanfaatannya. Semua peraturan tersebut barulah sebatas memfasilitasi kepentingan pengsaha (perseroan terbatas), bukan kepentingan rakyat atau masyarakat adat (lokal).

Dengan kata lain, hingga kini belum ada sebuah Undang-undang khusus mengatur mengenai Tanah Ulayat dan Pemanfaatannya (Peraturan Pelaksanaannya) secara nasional. Selain itu, dari beberapa pengaturan tersebut tidak terlihat dengan jelas keterkaitannya dengan Konstitusi (UUD 1945). Seharusnya, Konstitusi wajib dijadikan sebagai dasar utama pengaturan TU. Oleh karena TU adalah bagian dari .... 'bumi' .... dan TU itu terletak dalam yurisdiksi negara kesatuan Republik Indonesia (NKRI). Jadi, pengaturan TU wajib menjadi bagian dari Konstitusi. Apalagi, Konstitusi NKRI, dalam perubahan keduanya, telah mengakui keberadaan masyarakat hukum adat termasuk hak-hak tradisionalnya (tentu saja termasuk TU) sebagaimana tercantum pada Pasal 18 B Konstitusi:

\section{Negara mengakui dan menghormati kesatuan-kesatuan masyarakat hukum adat beserta hak-hak tradisionalnya sepanjang masih hidup dan sesuai dengan perkembangan masyarakat dan prinsip Negara Kesatuan Republik Indonesia, yang diatur dalam Undang-undang.}

Pentingnya pengaturan TU secara nasional dikarenakan TU tidak hanya dikenal pada satu daerah seperti di Minangkabau saja, melainkan juga terdapat di daerah Indonesia lainnya, seperti di Ambon, Kalimantan, Sulawesi Selatan. Justeru itu pengaturan TU secara nasional berupa Undang-undang sangat diperlukan. Misi pengaturan tersebut adalah untuk merumuskan pengelolaan, pengekploitasian (manajemen) TU dan keterkaitannya dengan hak-hak atas tanah lainnya serta untuk mengakhiri berbagai konflik horizontal dan vertikal atas TU.

Lebih spesifik, secara leksikal, seharusnya pengaturan TU dimulai dari upaya menerjemahkan kata 'bumi' seperti disebutkan pada ketentuan paal 33 ayat 3 UUD 1945 (Konstitusi). Kata 'bumi' selanjutnya dapat diterjemahkan kepada berbagai jenis pengaturan tanah, termasuk tanah ulayat, berikut pengaturan dan pelekatan (serta peralihan) hak di atasnya. Dengan cara demikian, pasti tidak akan terlihat jurang (gap) pengaturannya atau tidak akan 
terlihat perbenturan dalam pengekploitasian TU, baik oleh masyarakat lokal, oleh investor, atau oleh pemerintah (negara). Dalam hal ini patut dicatat bahwa pengaturan itu tidak harus menghilangkan karakter TU itu sendiri. Selain itu pengrunutan pengaturan pertanahan, termasuk TU, serta merta akan dapat mewujudkan pengaturan pertanahan yang systematis dan koheren.

Akar permasalahannya (root cause) dapat ditemukan pada tataran filosofis atau konseptual. Pada permasalahan tanah ulayat di Indonesia atau di Minangkabau khususnya, belum ada konsep pengekploitasian tanah ulayat itu sebagai satu standar yang berbasis konsep ekonomi kerakyatan yang berkeadilan sosial dan berkesinambungan. Ketiadaan konsep (miskonsepsi) pengeksploitasian TU itu tentu saja menimbulkan berbagai interpretasi dan bahkan menyulut berbagai konflik atau sengketa TU. Sesungguhnya, ketiadaan model manajemen TU yang ideal juga dipicu oleh ketiadaan konsep keadilan sosial (KS) sebagai nilai antara (pra-syarat utama) guna menciptakan kesejahteraan dan kemakmuran rakyat (ultimate value NKRI). Hingga kini kita belum pernah melihat sebuah definisi 'keadilan sosial' versi Indonesia baik yang diterima secara akademis oleh para pakar ataupun yang telah dimasukkan dalam berbagai perundang-undangan nasional Indonesia.

Miskonsepsi ini terbaca dari tidak ditemukannya penjelasan sila kelima Pancasila secara detil dan tidak ditemukan penjabarannya pada Undang-undang Dasar RI 1945 Amandemen serta juga tidak ada dalam berbagai peraturan perundang-undangan nasional lainnya. Miskonsepsi itu juga dipicu oleh ketidakpedulian pemerintah untuk memperjelas implementasi prinsip tersebut. Sebaliknyha, pemerintah bersama pembuat undang-undang mengadopsi konsep liberal (sekarang neo-liberal) dalam peraturan perundang-undangan seperti UU Perseroan Terbatas (PT), UU Penanaman Modal (Investasi), dan UU Persaingan Usaha, dll. Akibat pengabaian itu terjadi ekploitasi TU tanpa batas dan tidak memperhatikan kepentingan Masyarakat adat/lokal dalam menikmati hak-hak hidup yang layak, dan demi kesejahteraan mereka. Ketidak-perdulian pemerintah ini sekaligus menimbulkan ketidak-adilan dalam bernegara dan berbangsa. Pemerintah mengabaikan atau bahkan juga terkesan mempersempit arti dari "... dikuasai oleh negara dan dipergunakan sepenuhnya untuk kepentingan rakyat". Peran pemerintah semakin diminimalisir dalam memperhatikan kepentingan rakyat. Akibatnya, kita dan pemerintah (negara) menyaksikan, membiarkan lebih kurang 60 juta rakyat miskin per november 2012. Selain itu, alokasi sumber-sumber keayaan termasuk SDA dikuasai oleh sekelompok pengusaha (PT) kaya, konglomerat, bukan dikuasai dan dinikmati oleh semua rakyat secara merata.

Secara ekstrim dan teoretikal, KS versi Indonesia berbeda jauh dengan konsep keadilan yang dianut pada masyarakat komunis atau masyarakat barat. KS harus dibedakan dari konsep keadilan secara umum yang juga memiliki multi-interpretasi dan dimensi sesuai dengan nilai filosofis, aktivitas masyarakat, lingkungan dan nilai-nilai yang hidup pada masyarakat. Menerjemahkan KS menggunakan konsep keadilan versi filsuf barat juga menimbulkan suatu kekeliruan. Transplantasi nilai barat ke masyarakat indonesia tidak dapat dipaksakan, oleh karena nilai-nilai yang hidup dan 
berkembang pada masing masyarakat berbeda sesuai dengan ideologinya. Akibat miskonsepsi KS versi Indonesia ini telah membingungkan pelaksana negara, dan bahkan penegak hukum sehingga dengan mudah terdeviasi atau terintervensi oleh nilai-nilai keadilan yang dikemukakan oleh filsof barat. Akibatnya, pemanfaatan TU sering didominasi oleh ajaran keadilan yang disodorkan filsuf barat tersebut. Contoh yang lebih spesifik, keadilan menurut badan hukum PT (yang liberalis) belum tentu juga menciptakan rasa keadilan kepada rakyat lokal atau masyarakat adat. Makna keadilan sosial jadi mengambang dan aparat negara termasuk akademisi mudah dipengaruhi oleh ajaran atau teori keadilan versi barat atau sosialis. Seharusnya keadilan sosial dirumuskan dari nilai-nilai filosifis yang hidup dalam masyarakat indonesia dan diterjemahkan dengan rinci serta mudah diterapkan pada sektor ekonomi, sosial, politik, pertahanan dan budaya. Oleh karena itu penulisan kecil ini berusaha merumuskan konsep KS sesuai dengan nilai filosifis atau norma, adab yang hidup dalam masyarakat Indonesia.

Untuk keluar dari permasalahan di atas, penulis memandang perlu untuk membuat beberapa tawaran solusi, diantaranya: 1) perlu dibuat sebuah konsep pengekploitasian TU berdasarkan KS yang berkesinambungan untuk mewujudkan kesejahteraan dan kemakmuran rakyat Indonesia; 2) perlunya kebijakan publik baru tentang pengekploitasian tanah (termasuk TU) dalam mewujudkan ekonomi kerakyatan yang berkeadilan sosial; 3) perlu dilakukan proses revitalisasi atas masyarakat lokal dalam penikmatan hak-hak tradisionalnya; 4) perlu peningkatan perundingan yang efektif berbasis nilai dan kearifan masyarakat lokal guna mengurangi konflik pertanahan, termasuk konflik TU. Dari beberapa tawaran solusi tersebut, penulis hanyha memilih tawaran solusi pertama sebagai 'titik ungkit' untuk menyelesaikan permasalahan di atas. Untuk lebih detilnya, tawaran solusi yang dipilih perlu dirinci lagi menjadi beberapa poin penting: a) merumuskan konsep pengekploitasian $\mathrm{TU}$; b) pengkonsepsian ekonomi kerakyatan yang keadilan sosial (EKyKS) yang berkesinambungan dan; d) Pengeksploitasian TU berbasis EKyKS; e) beberapa kasus pengekploitasian TU secara hirtoris di Indonesia; dan d) Pengekploitasian TU dalam bentuk Proyek Revitalisasi Perkebunan, Industri, dan lainnya.

\section{Konseptualisasi Pengekploitasian Tanah Ulayat dalam Kerangka EKyKS}

Pada bagian kedua paper ini diskusi akan dibagi kedalam tiga kelompok yakni mengenai istilah pengekploitasian, pengekploitasian tanah ulayat, dan definisi tentang ekonomi kerakyatan yang berkeadilan sosial (EKyKS) yang berkesinambungan. Ketiga bagian itu dapat diperhatikan pada uraian berikut.

\section{Istilah Pengekploitasian}

Istilah ekploitasi dapat bermakna negatif dan positif. Pertama, ekploitasi dapat diartikan perlakuan atau pemanfaatan sesuatu secara 
tidak fair (adil). Dalam praktiknya, ekploitasi itu b erupa pengambilan keuntungan sendiri dan tidak adil atas seseorang atau situasi. Kedua, ekploitasi dapat berarti pembangunan atau pengembangan sesuatu untuk keuntungan agar memperoleh nilai lebih. Selain itu istilah pengekploitasian merujuk kepada kata 'exploitation', yang bermakna pemanfaatan oleh pihak pemilik sendiri atau dengan memberi izin (lisensi) kepada pihak lain. Untuk itu, pada sektor pertanahan, kata pengekploitasian perlu didefinisikan sebagai 'usaha untuk mencari manfaat dari kepemilikan tanah (bumi) beserta segala isinya, baik melalui kemampuan sendiri atau dengan bantuan pihak lain'. Jadi, dalam hal ini, prinsip utama yang perlu diperhatikan adalah bagaimana pengelolaan kepemilikan itu memberi manfaat (keuntungan) yang lebih adil kepada pemilik, bukan sebaliknya yakni manfaat lebih besar kepada pihak ketiga yang mengerjakannya.

\section{Pengekploitasian Tanah Ulayat}

Pada tanah ulayat, umumnya diolah, dimanfaatkan sendiri oleh anggota kaum, atau suku, atau anak negeri yang menguasai TU tersebut. Umumnya TU digunakan untuk lahan persawahan, perkebunan, atau kegiatan pertanian lainnya secara terus menerus dan turun menurun.

Selain itu, TU juga dapat dimanfaatkan oleh pihak ketiga atas izin pemilik TU yang bersangkutan. Izin tersebut diberikan baik dalam bentuk persetujuan lisan ataupun dibuat secara tertulis. Izin secara lisan lazimnya diberikan pemilik TU kepada pihak lain (berbeda suku) dalam bentuk bukti serah terima uang gadai. Izin tertulis diberikan kepada pihak ketiga, misalnya investor, untuk membangun perkebunan karet, sawit, atau dalam bentuk persewaan TU untuk keperluan bisnis, seperti persewaan Ruko, atau lahan untuk pergudangan, dan sebagainya.

Khusus pada pengeksploitasian TU untuk perkebunan, mulai sejak kemerdekaan hingga kini, dapat dicatat bahwa pemilik TU (kaum, atau suku, atau nagari) belum menikmati manfaat secara adil. Keuntungan yang lebih besar dinikmati oleh pihak pengekploitasi. Umumnya pemilik TU yang tinggal di desa hidup dibawah garis kemiskinan. Misalnya, pemilik TU yang digunakan untuk perkebunan teh, hingga kini hak-hak mereka terabaikan. Bahkan lebih dahsyat lagi, akibat pengekploitasian TU di Koto Panjang oleh PLN, masyarakat setempat selaku pemilik TU hidup dalam kemiskinan dan kesengsaraan. TU ulayat dialihfungsikan menjadi danau buatan untuk memutar turbin dan menghasilkan listrik. Akibatnya, masyarakat setempat kehilangan pencaharian atau penghidupan. Hal serupa juga terjadi di waduk kedung ombo. Banyak pengekploitasian TU lainnya yang juga menyengsarakan rakyat, namun jarang terpublikasi kepada masyarakat luas.

Selanjutnya, agar terhindar dari pengekploitasian dalam artian negatif, pengeksploitasian TU harus mengacu kepada konsep system perekonomian nasional. Dalam artian pengekploitasian TU itu berbasis 
kepentingan rakyat dalam koridor 'keadilan sosial' dan berkesinambungan. Untuk itu, bagian berikut akan menjelaskan definisi ekonomi kerakyhatan yang berkeadilan sosial dan berkelanjutan.

\section{Ekonomi Kerakyatan yang Berkeadilan Sosial dan Berkesinambungan}

Untuk mempertegas pengekploitasian TU, bagian ini akan mencoba membahas tentang ekonomi kerakyatan yang berkeadilan sosial dan berkesinambungan (EKyKS). Untuk mengkonstruksi rumusan EKyKS, sedikitnya, ada dua point penting yang perlu dijelaskan: i) paradigma EKyKS; ii) EKyKS sebagai sebuah system ekonomi nasional; iii) keadilan sosial sebagai ultimate value dari EKyKS. Masing-masingnya dapat diperhatikan dalam uraian berikut.

\section{Paradigma Tentang EKyKS}

Paradigma Ekonomi Kerakyatan yang berKeadilan Sosial merupakan sebuah konsep yang diusung penulis untuk mengklarifikasi bentuk system ekonomi nasional Indonesia yang diidealkan. Selama ini banyak istilah atau paradigma yang dikemukankan oleh para ahli ekonomi Indonesia, seperti 'ekonomi pancasila', 'ekonomi kerakyatan', dan sebagainya, namun paradigma itu masih perlu dibatasi lagi sehingga makin jelas dan mudah dimengerti serta dilaksanakan oleh siapapun.

Paradigma EKyKS ini ditarik dari pemahaman makna sila ke-lima Pancasila (keadilan sosial bagi seluruh rakyat Indonesia) dan pasal 33 (3) UUD 1945 (amandemen) yang menggunakan ide ekonomi kerakyatan. Sesunguhnya, system EKyKS merupakan opsi (keputusan bersama) yang dipilih oleh the founding fathers di NKRI ini. Selain merupakan konsensus nasional ketika negara Indonesia ini diproklamirkan, opsi itu juga sejalan dengan General Assembly Resolution 2625 (XXXV), 1970 yang menyatakan bahwa:

Each State has the right freely to choose and develop its political, social, economic, and cultural systems.

Kebebasan itu lebih ditegaskan lagi dalam article 1 General Assembly Resolution (XXIX) 1974 yang menetapkan:

Every states has sovereign and inalienable rights to choose its economic systems as well as political, social, and cultural systems in accordance with the will of its people, without outside interference, coercien, or threat in any form whatsoever.

Perumusan ini dimaksudkan untuk mengatasi ketiadaan konsep EKYKS yang dapat dijadikan pegangan pada penyelenggaraan pemerintahan dan pembangunan dalam NKRI. Untuk merumuskannnya, 
sedikitnya perlu dua langkah yang harus ditempuh. Langkah pertama adalah melihat EKyKS sebagai sebuah system. Langkah kedua adalah pengidentifikasian constructive elements guna merumuskan sistem EKyKS. Elemen-elemen tersebut akan ditilik dalam Pancasila sebagai grund norms dan UUD 1945 amandemen yang telah dijadikan acuan dasar pada penyelenggaraan dan pembangunan dalam NKRI.

\section{EKyKS Sebagai Sebuah Sistem Ekonomi Nasional}

EKyKS merupakan sebuah sistem ekonomi nasional yang berebeda dari sistem ekonomi negara lain, berbeda dari system ekonomi kapitalis dan system ekonomi sosialis. Berdasarkan pola berfikir system dan dengan memperhatikan UUD 1945 Amandemen, EKyKS terdiri atas empat properti: pemerintah, resources, mechanism, dan rakyat. Interrelasi antar keempat properti utama tersebut harus bekerja secara koherence, synergis, simultan, dan integrative untuk mencapai keadilan sosial guna mewujudkan dan mempertahankan negara Indonesia yang makmur dan sejahtera. Hubungan fungsional masing properti itu dapat diperhatikan pada uraian berikut.

\section{Pemerintah}

Pemerintah harus berfungsi sebagai aktor utama yang menjamin dan mempertahankan terwujudnya sebuah negara Indonesia yang maju dan sejahtera yang berpijak kepada prinsip keadilan sosial. Untuk tujuan tersebut, pemerintah diberi hak ekslusif (sebagai penyelenggara) oleh negara untuk menguasai sumber kekayaan: tanah, air, udara (ruang angkasa), dan sumber mineral dan gas. Penguasan dan manajemen itu harus mengikuti mekanisme yang tertuang dalam UUD 1945, peraturan pelaksanaanya pada berbagai sektor perekonomian nasional. Lebih spesifiknya, pemerintah wajib campur tangan (berperan aktif) melalui berbagai kebijakan untuk mengendalikan "cabang produksi yang penting/CPYP" dan "menyangkut hajat hidup orang banyak/MH2OB". Artinya pengeploitasian SDA wajib dikuasai oleh negara, dikendalikan sepenuhnya oleh pemerintah sebagai konsekuensi keberkedaulatan Indonesia atas SDA. Pemerintah memiliki powers (rights and duties) pada pengelolaan SDA. Misalnya, tarif listrik, harga beras, minyak dan gas diatur dengan bijaksana oleh pemerintah, tidak diserahkan pada mekanisme pasar. Mekanisme pasar hanya (dapat) terbuka pada segmen ekonomi nasional yang tidak menyangkut CPYP dan MH2OB. Untuk melaksanakan mekanisme perekonomian nasional sesuai UUD 1945 itu, pemerintah dituntut untuk mempunyai kinerja yang baik dan etika (mental model) yang selalu berdasarkan kepada keadilan sosial dalam rangka pendistribusian hak fundamental rakyat dibidang perekonomian untuk mensejahterakan dan memakmurkan rakyat. Oleh karena itu, mental koruptif yang dipicu oleh 'money politic' pada saat perekrutan (politik pengembalian modal dan cari untung sesaat) harus dikikis habis. 


\section{Sumber Daya Alam}

Bumi, air, udara (ruang angkasa) dan sumber mineral \& gas dipergunakan sepenuhnya untuk kepentingan rakyat. Keseluruhan sumber-sumber tersebut yang terletak di daratan (pulau-pulau), di dalam wilayah laut/udara \&ruang angkasa diatasnya, termasuk di dalam zona ekonomi ekslusif (ZEE) Indonesia harus sepenuhnya digunakan untuk kemakmuran seluruh rakyat Indonesia berdasarkan prinsip keadilan sosial. Oleh karena itu ekplorasi dan eksploitasinya harus berpijak kepada nilai-nilai 'keadilan sosial'. Artinya seluruh perjanjian terkait dengan eksploitas sumber daya alam ini bertentangan dengan keadilan sosial harus dikoreksi atau direvisi. Tambahan, tidak ada perjanjian penambangan mineral yang berpihak kepada kepentingan investor (domestik atau asing), namun harus menguntungkan rakyat Indonesia secara keseluruhan. 'Keadilan sosial' harus dijadikan meta (ultimate) value dalam pembuatan berbagai perjanjian tersebut. Untuk itu, pemerintah sebagai pelaksana mekanisme khususnya dalam pengekploitasian sumber daya alam (SDA) harus mengutamakan pemanfaatannya untuk kepentingan kemakmuran rakyat Indonesia.

\section{Mekanisme}

Mekanisme ini merupakan keseluruhan system hukum nasional bersifat koheren dan kerkesinambungan mulai dari UUD 1945 Amandemen, Goverment Regulations, its derivative rules. Semuanya mencerminkan system politik, ekonomi, sosial, dan budaya yang menjamin terwujudnya keadilan sosial bagi seluruh rakyat Indonesia. Oleh sebab itu konstruksi mekanisme ini harus dimaksudkan untuk berfungsi dalam upaya-upaya pencapaian 'keadilan sosial' guna mewujudkan negara Indonesia yang maju, sejahtera, dan makmur. Misalnya, peraturan dalam pengelolaan sumber daya alam harus dikonstruksi sebagai alur kebijakan yang memakmurkan atau mensejahterakan rakyat. Seluruh peraturan perekonomian nasional yang memarjinalkan rakyat harus dihapus. Peraturan tersebut harus dilaksanakan pemerintah tanpa pengecualian. Artinya 'equal before the law' harus diterapkan dalam proses peradilan, pemerintahan dan dalam praktek ketatanegaraan. 'Law enforcement' harus ditegakkan secara konsisten, tanpa pilih kasih, tanpa tebang pilih. Untuk itu, berbagai pengalaman negara maju seperti belanda, yang penduduknya multikultural perlu dijadikan contoh. Terakhir, kemakmuran dan kesejahteraan rakyat tidak akan terwujud tanpa penegakan hukum yang benar demi keadilan sosial.

\section{Rakyat}

Rakyat adalah property penting yang menjadi fokus perhatian dalam mewjudukan keadilan sosial untuk menjamin kesejahteraan rakyat 
Indonesia. Dalam hal ini rakyat mempunyai dua dimensi: 1) sebagai subjek; dan 2) sebagai objek. Sebagai subjek, rakyat harus bekerja secara simultan dengan properti lain dari sistem EKyKS. Artinya, rakyat, tanpa memperbedakannya, harus berpartisipasi untuk mewujudkan keadilan sosial demi negara sejahtera. Caranya adalah rakyat, secara bersamasama dengan pemerintah (yang juga bagian dari rakyat) berupaya mewujudkan sistem EKyKS.

Lebih konkritnya, rakyat dapat mengawasi pelaksanaan pembangunan versi sistem EKyKS oleh pemerintah. Untuk itu rakyat juga hartus tahu ukuran, indikator kemajuan dari pelaksanaan pembangunan tersebut.

Rakyat Indonesia yang identitasnya multi-kultural dituntut untuk menyambut baik kinerja pemerintah dalam memanfaatkan sumber daya (alam) berdasarkan perturan perundangan nasional yang hanya diperalat sebagai upaya untuk mencapai rakyat Indonesia yang makmur dan sejahtera serta berkeadilan sosial yang berkesinambungan. Sebagai salah satu syarat berdirinya negara Indonesia merdeka, rakyat harus diposisikan sebagai elemen penting (utama) dalam system ketatanegaraan. Pemerintah hanya berupa representasi (agen) dari keberadaan rakyat dan oleh karena itu pemerintah tidak perlu mengambil sikap terpisah, arogan (ekslusivist) ataupun takut kepada rakyat.

Sebagai objek, rakyat adalah sebagai pihak yang menjadi sasaran utama dalam bernegara. Rakyatlah yang akan diberikan 'keadilan sosial' dan sekaligus disejahterakan. Dengan kata lain, rakyat yang akan menikmati pemanfaatan sumber daya alam (SDA) yang dikelola oleh pemerintah sesuai mekanisme atau peraturan yang juga berdasarkan sistem EKyKS. Dengan demikian rakyat merupakan target atau sasaran utama dalam penyelenggaraan pemerintahan. Oleh karena itu, segala kebijakan publik (yang diterbitkan pemerintah atau penyelenggara negara lainnya) harus mengutamakan kepentingan rakyat demi terwujudnya keadilan sosial.

Keempat properties di atas haruslah memiliki interrelationship dengan peran yang sama, yakni untuk menciptakan perubahan yang diinginkan, yakni Indonesia yang maju, sejahtera dan makmur yang berkeadilan sosial. Dengan kata lain, seluruh komponen entitas EKyKS harus saling bekerjasama, bersinergi, terkoordinasi, dan simultan, konsisten serta koherence untuk mencapai ultimate value (state vision), yakni keadilan sosial untuk mewujudkan dan mempertahankan negara Indonesia yang makmur dan sejahtera. Ketidak-berfungsian salah satu komponen akan berakibat sulitnya mewujudkan mimpi NKRI alias tidak tercapainya visi NKRI.

Saat ini, system EKyKS boleh dikatakan tidak berfungsi, karena tidak terdapatnya mental model yang terus mengemban keadilan sosial untuk kesejahteraan dan kemakmuran rakyat Indonesia. Misalnya, mental model aparat pemerintahan yang koruptif menghambat pencapaian citacita NKRI. Justeru itu, mental model ini harus dibangun atas prinsip atau 
nilai-nilai kebersamaan (seperti keadilan sosial), bukan individual. Faktor lainya yang menyebabkan system EKyKS tidak berfungsi: keperpihakan pemerintah kepada investor dalam perdagangan, investasi, pelaksanaan peraturan perundang-undangan.

Secara teoritis, guna mewujudkan sinergi yang koheren antar elemen-elemen dari property, dua segi tiga pyramid berikut dapat dijadikan pedoman dalam mengemban terwujudnya keadilan sosial secara konsisten dan terintegrasi antar berbagai sektor perekonomian.

\section{Konsep Keadilan}

Keadilan (kata benda) terbentuk dari kata dasar 'adil' merupakan terminologi teoritis yang sebenarnya tidaklah begitu mudah diekpresikan dalam bentuk sebuah definisi. Makna kata adil itu tergantung kepada ruang, waktu, dan subjek dan oleh karena itu hingga kini masih terus diperdebatkan oleh para ahli filsafat dan ahli hukum. Banyak pendapat berbeda tentang apa sesungguhnya yang dimaksudkan dengan adil itu. Misalnya Heraclitus: 'justice is strife' (perselisihan). Ia menegaskan bahwa segala sesuatu yang terjadi berdasarkan perselisihan dan kepentingan'. Berbeda dengan Plato yang menyatakan 'justice as harmony'. John Lock mengungkapkan pula bahwa 'justice is manifest in the will of the person who made themselves citizens of a commonwealth by the social contract'.

Kemudian Habermas juga mengembangkan teori keadilan yang berpijak kepada apa yang disebut dengan discourse ethics. Istilah adil memerlukan kontek sosial. Beberapa pertanyaan mengenai benar atau salah, atau semua pertanyaan tentang makna kehidupan yang baik itu hanya dapat diputuskan oleh individual. Namun keadilan sosial termasuk percakapan antar pihak-pihak dalam perdebatan tentang cara terbaik untuk menyelesaikan konflik atas kepentingan yang beragam. Hal itu selalu bersifat interpersonal, dan selalu dilakukan dalam sebuah kontek kesejarahan secara khusus. Kemudian, Epicurus juga berargumen:

Justice arises when people make a"compact" together not to injure one another, and it is reasonable to be just as long as that compact pay off---in increased pleasure, of course. Justice, the, is wholly a matter of nomos for the Epicureans. It is true that justice and the other virtues are praised, but not only as means to a happy life for the individual (the honesty is the best policy syndrome).

Selain itu, Pelagius berpendapat bahwa 'setiap individu memiliki tanggung jawab atas kehidupannya dan terhadap keadilan Tuhan. Masing kita bertanggung jawab untuk mempertahankan hukum tuhan dan kita harus memelihara atau menghormati hukum itu, hukum itu harus mengikuti bahwa kita 'dapat' memeliharanya. Sebaliknya, ketidak-adilan Tuhan akan menghukum kita karena tidak melakukan sesuatu apapun'. Oleh karena itu, ia berargumen, kesempurnaan harus menjadi sesuatu 
yang mungkin bagi kita, karena hal itu diminta dari kita. Implikasinya adalah bahwa tiap individual yang terlahir kedunia bagaikan sesatu yang baru dan damai seperti Adam, dan masingnya memiliki kesempatan yang sama untuk memperoleh penghasilan, atau kebaikan, atau imbalan pada kehidupan yang abadi. Apakah seseorang itu selamat atau tidak, secara keseluruhannya ditentukan pada keinginan individual.

Berikutnya lagi, Aquinas menyatakan bahwa keadilan itu merupakan sesuatu yang mempengaruhi emosi kehidupan manusia. Dengan memaknai 'keadilan' dapat memastikan bahwa kita tidak berkecendrungan untuk mengambil lebih daripada pembagian barang kita, atau untuk memperlakukan diri kita sendiri lebih baik dari yang lain dalam pendistribusian barang. Keadilan distributif tidak berlaku banyak atas apa yang kita rasakan terhadap apa yang kita lakukan. Adil itu mengandung sebuah rujukan yang hakiki bagi yang lain. Untuk berlaku adil itu haruslah fair dan patut (pantas) dalam memberikan (membagikan) apa yang menjadi hak masing orang.

Selain itu, Aristoteles mengembangkan konsep 'justice' dari sebuah analisis ilmiah mengenai prinsip-prinsip rasional yang dikembangkan terhadap suatu latarbelakang dari bentuk hukum dan masyarakat politis yang ada. Titik temu diantara keduanya merupakan konsep kebaikan, ide yang mencakup semuanya yang mana keadilan merupakan bagian dan aspek penting. Menurutnya, keadilan lebih rendah dari kebijakan (wisdom), karena orang yang adil memerlukan orang lain dan bendabenda material untuk melaksanakan kebaikannya.

Dari pemikiran ini mengalir konsep tentang keseimbangan dan harmoni sebagai pengujian atas a just commonwealth dan a just individual. Lebih lanjut, bagi Aristoteles, harmoni merupakan titik tengah antara perbedaan yang ekstrim, yang disimpulkan oleh prinsip semi matematis pada sebuah paduan dari perbedaan yang ekstrim dalam pemerintahan dan hubungan manusia. Berbeda dengan Plato, harmoni merupakan suatu keadaan dari keseimbangan pemikiran yang lebih dalam yang tidak dapat dipahami dengan analisis rasional. Lebih lanjut, masih banyak pendapat filsuf tentang apa yang dimaksudkan dengan adil, seperti pendapat Homeric, Agustine, Sophist, Socrates, Anaximander.

Berikutnya, Rawls menyatakan bahwa konsep keadilan tidak hanya menjadi prasyarat untuk suatu komunitas manusia yang dapat berlangsung hidup, namun juga terkait dengan permasalahan sosial fundamental lainnya, khususnya mengenai koordinasi, efisiensi, dan stabilitas. Keadilan dalam skema sosial secara esensial tergantung tentang bagaimana hak-hak dan kewajiban fundamental ditunaikan dan mengenai peluang ekonomi serta kondisi sosial pada berbagai sektor masyarakat. Terakhir, Wright menyimpulkan bahwa konsep adil itu secara umum dipahami sebagai kondisi yang terdiri dari: a) equality atau fairness; b) dalam hubungan interpersonal; c) yang secara tepat tunduk kepada peraturan yang memuat hak-hak dan kewajiban hukum. 
Dari seluruh pendapat filsuf tersebut di atas, penulis menyimpulkan bahwa keadilan itu merupakan suatu kondisi keseimbangan, yang dalam Islam dikenal sebagai prinsip wasatha'. Prinsip ini dengan tegas dapat mewujudkan kedamaian (arti Islam itu sendiri) atau harmonis, baik dalam hubungannya dengan Tuhan (Allah SWT) ataupun dengan sesama manusia, termasuk dalam persaingan bisnis. Misalnya, untuk mewujudkan keseimbangan tersebut Allah SWT menciptakan manusia itu berpasang-pasangan, lelaki-perempuan. Pada tubuh manusia sendiri Allah SWT juga menciptakan serba dua: kiri-kanan. Misalnya pada tubuh manusia terdapat mata kiri-kanan, tangan kiri-kanan, paru kiri-kanan, ginjal kiri-kanan, dan kaki kiri-kanan. Semuanya berfungsi secara baik, tidak pernah terjadi fungsi yang berlawanan, apalagi saling melemahkan atau saling mematikan. Semuanya juga merupakan bentuk-bentuk keadilan Tuhan pada salah satu ciptaannya. Demikian pula keadilan Tuhan dapat ditemukan pada berbagai aspek lingkungan, baik darat, laut dan udara atau ruang angkasa. Jadi Tuhan lah yang dengan mahabijaksana dan dengan kekuasaannya menciptakan keseimbangan dimanapun, kapanpun dan dalam hal apapun, termasuk di bidang persaingan bisnis.

Oleh karena itu, memperdebatkan teori keseimbangan serta-merta juga mendiskusikan keadilan. Artinya, tanpa keseimbangan secara pasti tidak akan terwujud keadilan. Misalnya, keseimbangan hak dan kewajiban pihak pertama dan pihak kedua didalam sebuah perjanjian atau kontrak secara otomatis menciptakan rasa adil kepada pihak pertama dan kedua. Banyak contoh lainnya yang merefleksikan keseimbangan dan sekaligus keadilan. Dengan demikian dalam konsep keseimbangan sekaligus ditemukan konsep keadilan. Tegasnya, dua ekpresi kata memiliki satu makna. Hal itu dapat diekpresikan dengan sebuah ungkapan bahwa: 'Tidak ada keseimbangan, tidak akan terwujud pula keadilan'. Oleh karena itu, keduanya tidak dapat dipisahkan atau dipahami secara berbeda dengan standar nilai apapun.

\section{Keadilan Sosial Sebagai Ultimate Value dari EKyKS}

Untuk mewujudkan Indonesia yang sejahtera, dan makmur bagi seluruh rakyat Indonesia, keadilan sosial (KS) harus dijadikan ultimate value $(U V)$ dan wajib direalisir dalam praktik ketata-negaraaan. Selama ini KS hanyalah sebagai slogan untuk disebut-sebut dalam berbagai kesempatan pidato aparat pemerintah. Dalam penyelenggaraan perekonomian nasional, penulis menilai bahwa pemerintah hanya memperhatikan ketentuan pasal 33 UUD 1945 saja, tidak mempertimbangkan KS sebagai UV dan atau indikator utama. Akibatnya, deviasi, kontradiksi antar peraturan dasar dan berbagai peraturan pelaksananya telah memberi peluang besar kepada konsep ekonomi liberal untuk mengesampingkan system EKykS. Budaya koruptif yang semakin akut atau ketidak-disiplinan pengunaan keuangan 
negara merupakan bukti KS tidak menjadi perhatian penyelenggara negara/pemerintahan. Lebih kontras lagi, munculnya orang-orang indonesia terkaya yang memiliki aset trilliunan dolar AS. Selain itu, lebih kurang seperlima rakyat hidup dalam kemiskinan. Dua kondisi berbeda yang sangat ekstrim ini membuktikan ketidak-seriusan atau ketidakkonsistenan upaya pencapaian KS di Indonesia.

Selain disebabkan ketidak-konsistenan pemerintah dalam menegakkan norma-norma hukum terkait dengan KS pada masyarakat, semua kejadian di atas juga dilatarbelakangi oleh pengertian KS tidak terjelaskan secara ekplisit dalam perundang-undangan. Kegagalan pendefinisian KS itu lebih lanjut juga terbukti dari tidak menemukan satu dua pasal tentang pengelolaan, dan pengekploitasian sumber daya alam dimaksudkan untuk mewujudkan KS bagi seluruh rakyat indonesia. Oleh sebab itu, guna mengatasi ketidakjelasan pengertian KS, bagian ini dimaksudkan untuk merumuskan paradigma KS tersebut.

Secara linguistik, kata keadilan sosial (KS) merupakan satu frase yang terdiri atas kata 'adil' dan 'sosial'. Kata 'adil' bersifat universal, dan pada dasarnya bermula dari individual, yakni nilai-nilai keharmonisan, kebaikan, dan keteraturan (etika) yang hidup dalam tiap anggota masyarakat. Kemudian, perlu pula dipahami bahwa istilah keadilan dapat memiliki persamaan kata dengan fairness, equality, proporsionaliti. Penggunaan masing peristilahan tergantung kepada situasi dan kondisi kegiatan yang akan diukur dengan nilai-nilai dasar keadilan. Meskipun berbeda, substansinya adalah sama. Oleh karena itu, ketiga peristilahan itu memiliki tujuan akhir pada tiap kegiatan atau proses yang terkait dalam masyarakat. Sesuai dengan kondisi, lingkungan nilai-nilai masyarakat dan cakrawala pemikiran, para filsuf merumuskan keadilan dalam berbagai versi sesuai dengan kondisi dan tuntutan zamannya. Misalnyta, Aristoteles membagi keadilan kedalam dua jenis: distributive justice dan corrective justice. Dalam Wordworth Dictionary, keadilan dirumuskan sebagai "the quality of being just: integrity, impartially: rightness: the awarding of what is due: a judge, a magistrate".

Selanjutnya, 'keadilan sosial' adalah nilai etika yang terkristalisasi menjadi nilai social morality (SM) bagi seluruh anggota masyarakat Indonesia. Lebih konkritnya, nilai KS hidup berkembang dalam berbagai institusi: sosial, politik, ekonomi dan budaya. Secara konseptual, pandangan ini sejalan dengan pendapat Rawls yang mendefinisikan KS sebagai the justice of a social scheme depends essentially on how fundamental rights and duties as assinged and on the economic oportunities and social conditions in the various sectors of society'.

Lebih lanjut ia memformulasikan dua prinsip keadilan untuk institusi: Prinsip pertama: each person is to have an equal right to the most extensive total system of equal basic liberties compatible with a similar system of liberty. Prinsip kedua, social and economic inequalities are to be arranged so that they are both: (a) to the greatest benefit of the 
least advantaged, consistent with the just saving principle, dan; (b) attached to offices and positions open to all under conditions of fair equality of opportunity.

Istilah KS merujuk kepada keadilan dalam penyelenggaraan negara, namun berasal dari keadilan pada individu. Oleh sebab itu keadilan, menurut konsep Plato, harus merupakan satu ide yang menunjukkan pada sesuatu yang kita sebut dengan tepat adil (just). Dalam hal ini ada dikenal istilah just person, pemerintahan yang adil, hukum yang adil, dan tindakan pelelangan yang secara tepat menyebutnya 'just'. Semua yang "adil" di atas harus berpartisipasi dalam struktur tunggal yang merupakan keadilan ideal. Berbeda dengan John Locke, adil merupakan manisfetasi dalam keinginan orang yang membuat kewarga-negaraanan dari persekutuan berdasarkan kontrak sosial. Kemudian, keadilan itu ditemukan dalam jiwa (ethic) dalam mana seseorang merasakan kebahagiaan. Jadi keadilan individual itu berkorelasi dengan keadilan di dalam masyarakat (morally) yang disebut dengan keadilan sosial, yang semua orang menikmati rasa kepuasan atau kebahagian yang sama atas hal-hal tertentu. Dalam Islam, keadilan sosial itu dapat dicapai melalui dua cara: 1) Islamic Social Insurance; 2) Islamic Social Balance.

Misalnya keadilan sosial di bidang makanan, setiap warga negara berhak mendapatkan makanan yang layak, sehat, bergizi, dan harga terjangkau. Apabila terjadi ketidakadilan secara ekonomis, maka keadilan sosial harus dikoreksi hingga terwujudnya kondisi yang aman dan diterima semua pihak. Contoh lain, proses pendidikan masyarakat untuk memperoleh ilmu pengetahuan, khususnya masyarakat di pingiran kota, di pedesaan apalagi di daerah terisolir, harus menjadi perhatian negara untuk ditingkatkan menjadi sama dengan di kota. Akses kepada informasi terkini, berbagai sumber pembelajaran harus diberikan juga kepada mereka tanpa pembedaan.

Di Indonesia, KS secara tektual tertulis pada sila kelima Pancasila dan dua kali dalam pembukaan UUD 1945: 'keadilan sosial bagi seluruh rakyat Indonesia'. Sila kelima ini masih diperdebatkan dan belum pernah dirumuskan sebagai pedoman pembangunan perekonomian nasional. Selama ini keadilan sosial umumnya diterjemahkan dengan persamaan, keseimbangan, pemerataan. Padahal kata adil (justice) juga mengandung makna atau dimensi efisiensi, fair, terutama dalam penyelenggaraan pemerintahan di NKRI dan dinikmati oleh seluruh rakyat Indonesia.

Oleh karena itu, penulis perlu memperhatikan elemen konstitutif KS yang dapat terdiri dari: 1) nilai-nilai etika ( keharmonisan, keseimbangan, kebaikan, keteraturan, kenyamanan, ke-efisienan, ke-efektifan); 2) menikmati hak-hak fundamental dalam institusi sosial, politik, ekonomi, dan budaya; 3) kepuasan dirasakan atau dinikmati oleh seluruh rakyat Indonesia; 4) Sehingga pada gilirannya, nilai-nilai etika di atas bertransformasi dan terkristalisasi menjadi moralitas sosial yang disebut keadilan sosial. Dengan demikian penulis mencoba merumuskan KS sebagai: 
Nilai-nilai moralitas sosial yang hidup dalam institusi kemasyarakatan dalam bidang ekonomi, politik, dan budaya untuk menjamin pemenuhan atau penikmatan hak-hak fundamental seluruh rakyat Indonesia' secara berkesinambungan demi terwujudnya negara Indonesia berkemakmuran dan sejahtera.

Secara normatif dan parsial, KS , misalnya, sudah dijabarkan dalam pasal 27 (2) Konstitusi yang menyatakan: 'tiap-tiap warga negara berhak atas pekerjaan dan penghidupan yang layak bagi kemanusiaan'. Namun pengertian KS di bidang perekonomian ini khususnya jauh lebih luas dari itu. Makna KS di bidang perekonomian nasional perlu dielaborasikan dalam seluruh perundangan terkait di bidang perdagangan, kekayaan intelektual, investasi, penambangan sumber daya alam dan sumber mineral, transportasi, pendidikan, ketenagakerjaan, dan atau pada aktivitas ekonomi lainnya.

Selanjutnya, Pasal 33 (4) Konstitusi juga tidak dengan tegas menyebutkan 'keadilan sosial' sebagai salah satu prinsip utama penyelenggaraan perekonomian nasional. Akibatnya, kekosongan makna KS di bidang perekonomian pada konstitusi serta merta menyebabkan tidak terjelaskan prinsip KS pada berbagai perundang-undang nasional dan peraturan pelaksanaannya. Lagin pula, tidak satupun undang-undang yang merumuskan KS secara definitif. Kealfaan makna KS di bidang perekonomian ini mungkin disebabkan kegagalan pendiri negara, ahli hukum, atau ahli filsafat dalam mengkonseptualisasikan KS versi Indonesia. Kealfaan konsep KS teryata telah mempersulit pembuatan konsep ekonomi nasional. Untuk itulah sekarang penulis mengusulkan paradigma baru bagi system perekonomian nasional, yaitu EKyKS.

Idealnya, KS dijadikan sebagai salah satu ultimate value pada sektor ekonomi dalam mewujudkan ultimate goals (kesejahteraan dan kemakmuran) di Indonesia. Tidak akan ada kesejahteraan dan kemakmuran rakyat tanpa adanya KS. Oleh karena itu KS harus dijadikan sentral perhatian yang koherence dengan konsep ekonomi kerakyatan dan cita-cita nasional lainnya. Untuk itu KS perlu mewarnai perundang-undangan nasional di bidang ekonomi dan menjadi indikator utama dalam proses pembangunan perekonomian nasional. Dengan demikian mudah membedakan mana praktik penyelengaraan perekonomian nasional yang berkeadilan sosial dan yang tidak berkeadilan sosial. Dalam hal ini Konstitusi, khususnya pada pasal 34 telah mengantisipasi ketidak-adilan sosial tersebut seperti: 'fakir miskin dan anak-anak yang terlantar dipelihara oleh negara' dan 'memberdayakan masyarakat yang lemah dan tidak mampu sesuai dengan martabat kemanusiaan'. Ringkasnya, untuk mengentaskan ketidakadilan ini, pemerintah perlu mendirikan institusi khusus menangani permasalahan nasional tersebut.

Dalam hal ini perlu dicatat dan dipertegas mengenai pengertian 'dipelihara' oleh negara agar tidak terjadi salah interpretasi. Oleh karena 
kata 'dipelihara' dapat saja diartikan sebagai 'mempertahankan' status quo kemiskinan dan keterlantaran di tanah air. Oleh sebab itu, kata 'dipelihara' harus diterjemahkan sebagai tanggung jawab negara untuk membebaskan mereka dari kedua hal tersebut dan merevitalisasi pemenuhan hak-hak fundamentalnya. Tegasnya, menurut penulis bahwa negara berkewajiban untuk mengentaskan, menghapuskan kemiskinan dan keterlantaran tiap warga negara. Dengan kata lain, negara wajib menjamin pemenuhan hak-hak fundamental mereka sama seperti warga negara lainnya. Oleh karena itu, jaminan tersebut harus dituangkan dalam sebuah mekanisme pengentasan fakir miskin dan anak terlantar berupa per-undang-undangan tersendiri demi terwujudnya kepastian hukum dan KS serta kemakmuran rakyat.

\section{Dinamika Historis Pengekploitasian TU di Indonesia}

Secara historis, pengekploitasian TU telah melalui beberapa periode waktu berbeda, mulai dari pra-kemerdekaan, pasca- kemerdekaan, era orde baru, era reformasi, dan pasca reformasi. Masingnya dapat diperhatikan pada uraian berikut.

\section{Pada Masa Kolonial Belanda dan Jepang}

Pada era penjajahan Belanda, TU telah dikonversi menjadi tanah efrach yang dimanfaatkan VOC untuk perkebunan teh, tebu, pala dan sebagainya. Hal ini terjadi karena Belanda memberikan hak erfach (konsesi) tanpa batas-batas tanah yang jelas. Akibatnya, pemegang konsesi (hak erfact) memasukkan TU kedalam konsesinya. Okupasi TU berdasarkan konsesi itu sering memicu konflik antara pemegang konsesi dan masyarakat pemilik TU. Konflik atas TU juga terus berlanjut pada masa penjajahan Jepang. Jepang mengizinkan rakyat untuk menguasai tanah perkebunan milik pemegang erfach. Penguasaan kembali dimaksudkan untuk digarap oleh rakyat dan hasilnya dibagi dengan Pemerintah Pendidikan Jepang.

Pada masa kolonial ini, VOC juga mengambil kayu-kayu pada hutan di atas tanah ulayat yang kesemuanya itu dimaksudkan untuk keperluan ekspor atau perdagangan guna menghasilkan keuntungan (uang) bagi Kerajaan Belanda. Selain tidak diakui hak-hak rakyat atas tanah, rakyat (masyarakat adat khususnya) dipaksa untuk bekerja rodi/paksa tanpa menerima upah dan bahkan hasil pertanianpun seperti padi sering dirampas oleh VOC. Kondisi demikian telah memperburuk kehidupan rakyat yang hidup jauh dibawah garis kemiskinan akibat tekanan penjajah. Ketidakberdayaan rakyat untuk bangkit secara ekonomi tersebut juga terus berlanjut pada masa penjajahan Jepang. 


\section{Pada Masa Kemerdekaan}

Pada masa kemerdekaan, selain keberlanjutan konflik di atas TU, juga terdapat kesan bahwa pemerintah menghapus keberadaan TU dan mengabaikan eksistensi masyarakat adat (lokal) yang seharusnya menjadi prioritas perhatian secara penuh. Penghapusan tersebut terbukti dengan dikeluarkannya berbagai peraturan perundang-undangan di bidang pertanahan, perkebunan dan kehutanan. Misalnya Pemerintah mengeluarkan Keputusan Presiden nomor 32 Tahun 1979 tentang konversi hak-hak barat menjadi tanah negara dan kebijakan berkutnya yang berakibat seluruh tanah yang dikuasai belanda untuk perkebunan harus dialihstatuskan menjadi tanah negara, apakah tanah tersebut berasal dari tanah ulayat atau hak-hak atas tanah lainnya. Seharusnya tanah efrach itu dikembalikan dan dikelola oleh anggota masyarakat adat guna menopang kehidupan perekonomian mereka yang lebih baik.

Kekeliruan pemanfaatan atau manajemen TU oleh pemerintah juga terlihat pada berbagai peraturan perundang-undangan yang diterbitkan, seperti Undang-undang (UU) nomor 5 Tahun 1967 tentang Pokok Kehutanan yang telah dirubah dengan UU no. 41 Tahun 1999 yang memberi konsesi kepada investor (badan hukum) untuk mengkoversi hutan (TU atau ulayat nagari) menjadi hutan tanam industri (HTI) dan perkebunan. Pemerintah memberikan hak guna usaha (HGU) untuk perkebunan kepada perseroan terbatas (badan hukum) selama 60 tahun dan dapat diperpanjang 30 tahun berikutnya dengan alasan untuk mendorong kemajuan perekonomian nasional. Setelah 90 tahun, tanah HGU yang semulanya berasal dari TU itu dikuasai oleh negara (tanah negara), bukan dikembalikan kepada rakyat (masyarakat adat/lokal). Selain itu masih banyak peraturan yang memarjinalkan hak-hak masyarakat adat (lokal), seperti Peraturan Pemerintah (PP) nomor 21 Tahun 1970 tentang Konsesi Hutan dan Konsesi Produk Hutan, Peraturan Pemerintah (PP) nomor 29 Tahun 1985 tentang Perlindungan hutan, UU nomor 11 Tahun 1967 tentang Ketentuan Pertambangan, dan UU nomor 5 Tahun 1990 tentang Konservasi Sumber Daya Alam Hayati dan Ekosistemnya.

Banyak dampak yang ditimbulkan akibat pengabaian atau pemarjinalisasian hak-hak masyarakat adat yang dapat dilihat saat ini. Pemerintah lebih memberikan privilege khusus kepada perseroan terbatas (PT) atau investor berupa keleluasaan untuk pengekploitasian dan pengeplorasian sumber daya alam (SDA). Khusus pada bidang kehutanan, eksploitasi TU oleh PT baik nasional atau asing berupa proyek Perkebunan Inti Rakyat (PIR) yang diwujudkan dalam skema pembagian keuntungan $70 \%$ untuk PT dan 30\% untuk anggota masyarakat adat. Disini jelas porsi $30 \%$ untuk masyarakat tidak mencerminkan keadilan guna merubah kemiskinan menjadi masyarakat yang sejahtera. 
Di bidang pengelolaan sumber daya alam lainnya juga menimbulkan dampak yang merugikan langsung kepada anggota masyarakat. Misalnya, Pada pembangunan waduk Kedung Ombo di Jawa Timur dan pembangunan waduk Koto Panjang di Pekanbaru. Kedua kasus ini menjadi saksi kepada publik bahwa pemerintah betul-betul merampas hak-hak masyarakat tradisional. Pengambilalihan TU telah memiskinkan, menyengsarakan masyarakat lokal dan bahkan makin jauh dari standard kehidupan normal. Kedua bentuk pencaplokan TU membuktikan betapa ketidakberpihakan pemerintah (negara) kepada mereka sekaligus juga mengabaikan penghormatan hak azazi manusia (HAM) mereka seperti hak untuk hidup secara layak.

Lebih lanjut, secara yuridis, pelanggaran HAM tersebut telah memicu konflik vertikal antara masyarakat lokat (adat) dengan pemerintah, dan investor, seperti Perusahaan Listrik Negara (PLN) yang memanfaatkan lahan TU untuk genangan air pembangkit listrik. Konflik tersebut telah mengundang simpati masyarakat internasional, khususnya Jepang dan mendesak pemerintah Indonesia untuk peduli atas penghormatan HAM dari masyarakat adat (lokal) dalam pembangunan proyek-proyek yang memanfaatkan SDA.

Dari kejadian kedua konflik vertikal tersebut dapat dipahami atau disadari bahwa pengakuan TU oleh UU Pokok Agraria (pada pasal 3 UU nomor 5 Tahun 1960), UU Kehutanan, UU Perkebunan, Peraturan Daerah (misalnya Sumatera Barat), Keputusan Lembaga Kerapatan Adat Alam Minangkabau (LKAAM) dan keputusan Kerapatan Adat Nagari (KAN) tidaklah cukup untuk melindungi hak-hak tradisional masyarakat lokal (adat). Banyak hal yang luput dari pengaturan demi terwujudnya pengelolaan Tu yang baik dan ideal. Hal itu dikarenakan tidak adanya system atau skema manajemen pemanfaatan TU yang berbasis kepada norma/nilai-nilai dan peraturan yang lebih tinggi guna menjamin penghormatan HAM dan kepastian hukum untuk hidup secara layak. Lebih jauh, ketidaksingkronan pengakuan TU pada berbagai peraturan di atas dengan Sila kelima Pancasila: 'keadilan sosial bagi seluruh rakyat Indonesia' dan kekeliruan interpretasi pasal 33 UUD 1945 (amandemen) menghendaki sebuah model manajemen TU yang ideal guna mewujudkan masyarakat adat yang adil, makmur dan sejahtera sebagai bagian dari rakyat Indonesia secara keseluruhan.

\section{Pada Era Reformasi}

Pada era ini terlihat tidak banyak perubahan dari masa sebelumnya. Mekanisme pengeksploitasian TU masih berupa pola bagi hasil, dan sering pula terjadi pengalihan atau perubahan status, dari hak atas TU ke hak erfach, atau ke hak pakai, dan tidak pernah dikembalikan kepada pemilik TU sesuai kesepakatan awal. Kemudian, pemuliahan hak-hak tradisional masyarakat hukum adat dalam TU nya juga belum terlihat. Misalnya, hak-hak tradisional masyarakat Koto Panjang, yang lahan 
mereka dijadikan waduk (danau buatan) untuk pembangkit listrik oleh PLN. Hingga kini hak-hak mereka untuk memenuhi kebutuhan fundamentalnya belum menjadi perhatian pemerintah.

Pada masa reformasi atau pasca reformasi, situasi pengekploitasian TU masih berlanjut. Izin-izin HPH di atas TU tertus dikeluarkan pemerintah. Kemudian, pengkonversian TU berakibat kemiskinan dan kesengsaraan rakyat juga terus menjadi fenomena yang tidak asing. Akibatnya, konflik pmanfaatan TU terus bertambah dan sangat sedikit yang terselesaikan.

\section{Pengekploitasian TU Berbasis EKyKS}

Selama ini, pemanfaatan atau pengekploitasian TU di Indonesia hanya menguntungkan investor atau pemerintah, tidak mensejahterakan rakyat. Kesimpulan sementara ini sangat sulit dibantah, karena hingga kini masih terdapat lebih kurang 60 juta rakyat miskin yang hidup di desa-desa, pergunungan, daerah terisolir yang belum menikmatik infra struktur umum yang moderen, seperti listrik, jalan raya yang bagus, sekolah, dan rumah sakit. Selain itu, sikap pemarjinalan rakyat yang hidup di atas TU oleh pemerintah dan keberpihakan pemerintah kepada investor telah membuat atau menyisakan berbagai permasalahan, mulai dari kemiskinan, kesengsaraan, dan keterpurukan ekonomi. Sesungguhnya, munculnya permasalahan tersebut disebabkan oleh ketidak-seriusan pemerintah dalam menjalankan system EKyKS. Ketidak seriusan itu diperburuk lagi oleh keengganan pemerintah merumuskan konsep EKyKS yang mengutamakan rakyat.

Seharusnya, di NKRI yang merupakan negara hukum, seluruh aktivitas kenegaraan wajib berpedoman kepada hukum, terutama kepada Konstitusi (UUD 1945). Dengan kata lain, seluruh aktivitas perekonomian sudah seharusnya merujuk pada system perekonomian nasional, yakni ekonomi kerakyatan sebagaimana tertuang dalam ketentuan pasal 33 (1) dan (2) UUD 1945. Demikian pula dengan aktivitas perkonomian di bidang pertanahan, khusus pengeksploitasian TU. Pengekploitasian TU juga harus berbasis pada system EKyKS yang berkesinambungan. Tanah ulayat beserta kekayaan atau sumber mineral (emas, batubara, minyak, gas, dan lainnya) baru dapat dimulai pengeksploitasiannya setelah jelas kondisi atau arah pengeksploitasiannya. Namun, selama ini, tidak jelas arah pengeksploitasian TU dan seakan-akan terlepas dari pelaksanaan pasalpasal Konstitusi.

Guna mewujudkan rakyat yang sejahtera dan makmur, pengaplikasian system EKyKS merupakan pra-syarat utama. Pemerintah dituntut untuk mereformasi peraturan perekonomian nasional, termasuk di bidang pertanahan. Ringkasnya, pemerintah wajib memberikan perhatian maksimal kepada rakyat di desa, hutan yang hidup diatas TUnya. Dengan memahami segala permasalahan, kekurangan rakyat di desa 
atau hutan di atas TU mereka, pemerintah memang telah menerbitkan semacam peraturan pemerintah untuk mengaktivasikan potensi mereka melalui program revitalisasi.

Dari program tersebut memang terlihat semangat pemerintah untuk merubah keadaan rakyat miskin di pedesaan atau hutan dan menyediakan puluhan trilyun rupiah. Namun ketersediaan dana itu tidak merubah keadaan, oleh karena pemerintah tidak mengeluarkan sebuah panduan atau 'model pembangunan' dalam bentuk proyek 'revitalisasi'. Akibatnya, dana itu sebagian besar tidak terserap habis tiap tahunnya, dan masih menjadi komitmen penyediaan dana oleh pemerintah. Jadi, pengeksploitasian TU selain berpedoman kepada system EKyKS yang konstitusional, juga perlu diperhatikan kondisi rakyat tersebut.

\section{Revitalisasi Pengekploitasian TU demi Kesejahteraan Rakyat}

Dari skema pengeksploitasian TU selama ini yang bedoman kepada perjanjian bagi hasil (Pola Bagi Hasil, disingkat dengan $\mathrm{PBH}$ ), dalam mana pembagian prosentasenya lebih besar untuk investor, sedangkan pemilik TU hanya mendapatkan prosentasi kecil. Misalnya Perjanjian Kerjasama pembangunan perkebunan kelapa sawit, dalam mana investor disepakati akan memperoleh $70 \%$, sedangkan pemilik TU akan memperoleh $30 \%$. Kadangkala, perolehan hak $30 \%$ itu tidak pula diterima sepenuhnya oleh masyarakat yang berhak, namun diserahkan perusahaan kepada masyarakat lain di luar area perkebunan, bahkan uang pembagian yang 30\% itu diberikan perusahaan pengelola perkebunan sawit kepada oknum pejabat dan disalahgunakan untuk keperluan pemilukada. Akhirnya, rakyat yang berada pada posisi lemah cendrung dibohongi dan diabaikan oleh pemerintahnya sendiri.

Untuk mengatasi permasalahan di atas, penulis mencoba mengusulkan ' $a$ possible solution, dengan argumen bahwa model manajemen TU yang ideal setidaknya harus memenuhi tiga kondisi berikut. Pertama, pemanfaatan TU (khususnya hutan) harus disinkronkan dan dibuat koheren dengan prinsip 'keadilan sosial bagi seluruh rakyat Indonesia' dan Pasal 33 UUD 1945 (amandemen) tersebut di atas. Kedua, secara konkrit, seluruh perkebunan PIR harus dihapuskan dan dirubah dengan pola perkebunan plasma. Ketiga, alokasi dana negara/pemerintah atau dana asing yang diperuntukkan pengentasan kemiskinan harus diserahkelolakan kepada PT yang ditunjuk mengasuh petani perkebunan plasma dan diikuti dengan mekanisme yang jelas serta transparan. Dengan demikian pemerintah tidak perlu lagi membagikan BLT kepada masyarakat miskin atau anak yatim yang tidak merubah perekonomian rakyat. Jika perlu pemerintah juga mewajibkan setiap WNI yang miskin baik yang tinggal di perkotaan atau pedesaan untuk ikut terlibat pada proyek perkebunan plasma atau proyek pertambangan plasma sehingga dalam waktu singkat kemiskinandapat dihapus di negeri yang kaya dengan SDA ini. Lebih konkritnya, konsep revitalisasi dalam kontek pengekploitasian TU dapat diperhatikan uraian berikut. 


\section{Konsep Revitalisasi Pengeksplolitasian TU}

Sebenarnya, ide atau paradigma 'revitalisasi' perlu klarifikasi kedalam sebuah konsep nyata yang mudah dilaksanakan oleh siapapun. Namun sangat disayangkan, pemerintah tidak menyiapkan konsep tersebut untuk diterima, diakui dan dibudayakan secara luas oleh masyarakat. Secara yuridis, pemerintah telah mengeluarkan Peraturan Menteri Pertanian no. 33/Permentan/OT.140/2006 tentang Pengembangan Perkebunan Melalui Program Revitalisasi Perkebunan. Namun peraturan itu tidak mengatur secara rinci tentang bagaimana melaksanakan program revitalisasi tersebut. Hasilnya, dana revitalisasi yang jumlahnya ratusan milyar rupiah yang dianggarkan pemerintah tiap tahunnya hampir tidak tercairkan sama sekali.

Justeru itu, tulisan ini juga mencoba memformat sebuah konstruksi ide tentang revitalisasi aktivitas perkebunan yang dilakukan di atas lahan TU. Secara prinsip, kata revitalisasi perlu diterjemahkan sebagai usaha untuk merubah status rakyat miskin yang hidup di desa, lembah atau pergunungan yang belum menikmati fasilitas instrastruktur publik dan tidak mampu mengaktivasi potensinya menjadi rakyat yang berpenghasilan menengah atau lebih. Ide untuk merubah dari yang tidak berpenghasilan tetap kepada berpenghasilan tetap setiap bulannya. Selanjutnya, ide tersebut dapat diterjemahkan secara teknis atau detil seperti tetuang dalam uraian berikut ini.

Pada proyek revitalisasi, perkebunan plasma ini masyarakat adat diberi hak sepenuhnya untuk mengelola hutan TU-nya sendiri untuk kesejahteraan mereka sendiri. Oleh karena itu mereka berhak $100 \%$ dari keuntungan yang mereka kerjakan dibawah payung sebuah koperasi yang mereka dirikan. PT hanya berperan sebagai avalis (penjamin) atau seperti 'bapak asuh' untuk menjamin kelancaran usaha perkebunan plasma dengan meminjamkan talangan dana (tanpa agunan apapun) yang bersumber dari perbankan. PT akan mencairkan dana secukupnya via koperasi demi kesuksesan usaha petani plasma tanpa mencari keuntungan dari pengucuran dana tersebut. Dana talangan ini akan dibayar kembali petani setelah panen mereka sukses sehingga tidak memberatkan mereka.

Dana talangan perusahaan dapat juga diganti dengan dana perbankan. Jelasnya, koperasi meminjam kepada pihak perbankan dengan jaminan surat ukur tanah (atau sertifikat tanah). Pihak perseroan berfungsi sebagai penjamin atas pinjaman koperasi. Perseroan Terbatas (PT) menjamin hutang koperasi dilunasi sesuai tenggat waktu yang ditetapkan kedua pihak. Justeru itu PT harus memastikan setiap tahapan perkebunan berjalan sesuai dengan jadwal, dan jika perlu dipercepat dari skedul kegiatan pembangunan perkebunan yang ditetapkan.

Selain itu, sebagai 'bapak asuh, PT akan memberdayakan mereka dengan memfasilitasi atau penyediaan keahlian manajemen (teknologi), berbagai peralatan yang dibutuhkan sesuai dengan jenis pertanian atau perkebunan yang mereka usahakan, serta fasilitas umum seperti jalan, 
transportasi, komunikasi, pasar, rumah sakit, sekolah dan jaminan sosial lainnya. Semuanya itu lebih dari sekedar implementasi dari CSR (corporate social responsibility) sebagaimana yang dicanangkan pemerintah kepada perseroan terbatas dalam operasi bisnisnya. Oleh karena itu PT hanya akan memperoleh 'management fee' sebesar 5\% dari pemerintah. Keuntungan yang akan diperoleh oleh PT berasal dari laba penjualan sawit ke khususnya pasar internasional. Untuk itu, PT akan diharuskan membeli semua produk seperti sawit, jagung dan produk lain yang dihasilkan petani plasma dengan harga yang pantas dan jikalau memungkinkan di atas harga pasar lokal atau nasional. PT akan diberi hak untuk mengolah sendiri menjadi produk jadi atau menjualnya ke pasar nasional atau internasional. Dengan skema 'mutual symbiosis' ini diharapkan petani perkebunan plasma dapat dipastikan menikmati sebuah mimpi kehidupan perekonomian lebih dari layak, makmur dan sejahtera sesuai dengan amanah Pembukaan UUD 1945 Amandemen.

\section{Proses Revitalisasi}

Selanjutnya, untuk membuat perubahan yang ekstrim itu, ide merevitalisasi raykat miskin ke rakyat yang kaya harus melalui suatu proses yang jelas dan tegas. Proses itu, pada uraian berikut, akan dibahas dalam masa persiapan, masa pelaksanaan, masa evaluasi seluruh aktivitas program revitalisasi perkebunan tersebut.

Masa persiapan (pra-kondisi), Perusahaan calon avalis mendatangi masyarakat lokal yang memiliki TU untuk diolah menjadi perkebunan sawit, atau karet atau coklat. Perusahaan perlu melakukan pendekatan dalam bentuk pertemuan formal atau informal guna menyamakan visi bahwa program revitalisasi memerlukan kerjasama yang baik, serius, dan harmonis antar kedua pihak. Masyarakat perlu merubah persepsi bahwa perusahaan calon avalis yang datang ke daerahnya bukanlah investor, tetapi penjamin. Perusahaan calon avalis menjamin perkebunan sawit berhasil, dan juga menjamin pelunasan hutang (kedit) perbankan sesuai skedul waktu yang disepakati dengan pihak perbankan. Dalam hal ini tidak ada kerjasama pola bagi hasil. Semua hasilnya diserahkan kepada rakyat (masyarakat adat terkait). Untuk itu perlu dibangun 'prinsip kesaling-percayaan antar kedua pihak'. Selain itu, perusahaan calon avalis melakukan survey lahan bersama masyarakat terkait dan memastikan lahan tersebut tidak bersengketa dengan pihak manapun. Setelah itu perusahaan calon avalis menyampaikan kepada masyarakat untuk menyiapkan dokumen: kartu tanda penduduk, surat pernyataan kaum, atau kelompok bahwa mereka memiliki, menguasai TU, dan dokumen terkait lainnya. Masyarakat diharuskan membentuk kelompok tani dan semua kelompok itu bergabung membuat satu koperasi, yang nantinya akan mengadakan hubungan hukum kontraktual dengan perusahaan calon avalis. 
Pada tahapan ini, setiap (masingnya) anggota masyarakat adat dipastikan akan mendapat lahan seluas 4 hektar (ha.) untuk digarapnya. Jadi lahan dengan luas tertentu dibagi dengan anggotanya, yang masing anggota keluarga mendapat satu kapling seluas 4 ha. Dengan luas kebun sawit seperti itu, jika menghasilkan dan panennya bagus, masing mereka direncanakan untuk berpenghasilan sekitar Rp. $6-8$ juta per bulan. Tentu saja, anggota masyarakat yang janda, buta, atau yang disable lainnya diberikan prioritas utama, karena ketidakmampuannya secara fisik atau mental.

Setelah pengkaplingan lahan sesuai dengan rencana di atas, perusahaan membantu pengurusan dokumen sertifikat untuk kemudian diagunkan ke Perbankan. Masing kapling dimiliki tiap anggota masyarakat $100 \%$ berikut dengan sertifikat tanahnya. Dalam hal ini, perusahan avalis perlu mengingatkan bahwa mereka tidak diperkenankan menjual lahan yang mereka miliki sampai kapanpun agar konsep komunal (TU) terus dipertahankan. Meskipun proyek revitalisasi ini berakhir, kewajiban 'tidak boleh menjual' ini terus dipertahankan dan dinyatakan dalam sertifikat. Selain itu, perusahaan calon avalis membantu pengurusan dokumen izin perkebunan, peta lahan, dan sebagainya. Selain itu, kesepakatan kedua pihak perlu dirumuskan dalam bentuk perjanjian kerjasama pembangunan perkebunan kelapa sawit dengan model proyek revitalisasi. Jadi semua hal terkait persiapan juga dituangkan dalam perjanjian tersebut, dan demikian juga semua hak dan kewajiban kedua pihak pada tahap pelaksanan dan evaluasi perlu dituangkan dalam perjanjian tersebut. Semuanya itu termasuk hasil kajian-kajian teknis perlu disampaikan kepada masyarakat untuk dipahami dan dipastikan semua hal yang disepakati diatur dalam perjanjian.

Sebelum perkebunan dimulai dan sambil menyiapkan (pembersihan) lahan, perusahaan avalis memberdayakan masyarakat untuk melakukan penanaman sela, seperti bunga ross, jagung, atau sejenis untuk memberi penghasilan awal kepada masyarakat. Pada tahap ini, PT bekerjasama dengan masyarakat mulai membangun jalan untuk kebutuhan transportasi jangka panjang yang lancar. Untuk itu jalan yang akan dibangun adalah jalan beton dengan konstruksi standart yang dibiayai oleh penjualan kayu yang diambil dari lahan yang akan dijadikan perkembunan kelapa sawit. Masyarakat mengerjakan pembangunan jalan tersebut secara bergotong royong dan difasilitasi dengan alat berat yang disediakan perusahaan.

Pada masa pelaksanaan, semua kewajiban masyarakat dan perusahaan avalis dipastikan berjalan dengan baik. Mulai dari pembersihan lahan, penyediaaan bibit, pemupukan, pemanenan, pemasaran buah sawit segar, jika memungkinkan diolah sendiri oleh avalis, sehingga harga jual buah sawit segar tersebut tidak mudah dikendalikan oleh perusahaan besar. Hal prinsip lainnya, pada masa pelaksanaan ini ketika panen telah mulai, avalis juga telah memulai membayar angsuran kredit ke perbankan yang diambil atau dipisahkan 
dari uang hasil penjulan sawit. Pada saat bersamaan, dokumen terkait juga perlunasan kredit itu dipastikan telah dalam proses yang benar.

Pada masa evaluasi, perusahaan avalis dituntut untuk melakukan evaluasi kapan saja selama masa perjanjian berlangsung dan sesudahnya, sesuai dengan ketentuan perjanjian. Hal ini perlu dilakukan perusahaan avalis agar kepastian atas terwujudnya perkebunan sawit (karet, coklat, atau usaha penangkapan ikan di laut misalnya), dan kepastian perlunasan kredit perbankan betul-betul terrealisir dengan baik sesuai skedul.

\section{Hambatan Program Revitalisasi}

Meskipun bagusnya konsep program revitalisasi di atas, namun bukan berarti tidak ada hambatan. Diantara hambatan tersebut adalah sebagai berikut:

1) Masih rendahnya pengetahuan (pendidikan) masyarakat sehingga berakibat rendahnya kesalingpengertian-atau kesepahaman mengenai proyek yang akan dikerjakan; Masyarakat masih berpikiran bahwa sebuah PT datang hanya akan merugikan mereka saja, alias mencari untung sepihak saja, tidak mensejahterakan masyarakat;

2) Ketidak-saling-percayaan masyarakat dalam bekerjasama dengan perusahaan. Umumnya masyarakat beranggapan bahwa perusahaan yang datang itu adalah investor yang tidak membawa perubahan atau keuntungan kepada masyarakat.

Untuk mengatasi hambatan tersebut, perlu dilakukan penelitian khusus untuk itu guna menemukan solusinya.

\section{Penutup}

\section{Simpulan}

Dari uraian di atas, penulis menyimpulkan beberapa hal pokok sebagai berikut:

1) Pengekploitasian atau pemanfaatan TU, mulai pada masa penjajahan Belanda, penjajahan Jepang, pasca kemerdekaan, orde baru, era reformasi dan pasca reformasi, tidak terkelola dengan baik, selalu menimbulkan konflik (sengeka) serta tidak memberikan keadilan kepada seluruh anggota masyarakat.

2) Untuk merubah pengekploitasian atau pemanfaatan TU yang berpihak kepada rakyat, manajemen TU harus berbasis atau merujuk kepada system EKyKS, dalam system mana keadilan sosial versi Indonesia harus dijadikan ultimate velue.

3) Untuk mewujudkan pengekploitasian TU berbasis sistem EKyKS, program revitalisasi perkebunan, yang dielaborasi dengan kebijakan pemerintah menawarkan, dan menyediakan 
dana, program revitalisasi harus dikonseptualisasi sedemikian rupa dan memberikan kejelasan pada pengesploitasian TU pada berbagai perkebunan sawit, teh, karet, dan coklat.

\section{Saran}

Dari beberapa kesimpulan di atas, penulis menyampaikan saran sebagai berikut:

1) Untuk menindak-lanjuti program revitalisasi masyarakat rakyat, pemerintah terlebih dahulu mengidentifikasi kendala-kendala dan menghapusnya, termasuk pengidentifikasian berbagai jenis transaksi atas lahan yang akan dijadikan proyek revitalisasi;

2) Program Revitalisasi yang luncurkan tersebut memerlukan pengawasan pemerintah apakah sudah sesuai dengan Konstitusi (UUD 1945) atau cita-cita NKRI.

3) Pemerintah diharapkan segera mengumumkan konsep resmi systek EKyKS untuk dipedomani dalam berbagai aktivitas perekonomian nasional termasuk dalam pengekploitasian TU;

4) Konsep revitalisasi masyarakat pedesaan ini diharapkan juga bisa diaplikasikan pada sektor usaha perikanan yang masyarakat nelayannya juga menempati posisi yang tidak jauh berbeda dengan masyarakat pedesaan.

5) Meskipun program revitalisasi ini dapat dilakukan pada sektor perkebunan, terutama pada pembangunan perkebunan kelapa sawit (kecuali karet atau cokelat karena hasilnya mudah dijual langsung oleh masyarakat pemilik kebun, justeru itu pihak perbankan tidak akan bersedia mendanai proyek revitalisasi pada karet dan cokelat), konsep revitalisasi di atas dapat juga diaplikasikan pada proyek revitalisasi nelayan pantai untuk penangkapan ikan din laut untuk merubah kondisi perekonomian dan lingkungannya menjadi lebih baik, maju, dan moderen. 


\section{Daftar Pustaka}

\section{Buku}

Awang, San Afri. Politik Kehutanan Masyarakat, Cetakan I, Yogyakarta: Kreasi Wacana, 2003.

Barry, Brian. Theory of Justice, A treaties on Social Science, A Treatise on Social Justice, vol.1, Harvester-Wheatsheaf, 1989.

Campbell, Henry. Black Law Dictionary, Abridge Six Edition, West Publishing, Co, 1991.

Center for Dispute Resolution, Alternative Dispute Resolution, Faculty of Law, University Technology of Sydney/UTS, Australia, 1995.

CDR Asociate, Power and Influence: The Disputan and Mediators Sources of Power, 1992.

Conflict Management Group/CMG, Material ADR Training, Palembang, 1998.

Coyle, Sean Pavlakos (eds.), Jurisprudence or Legal Science, Hart Publishing, Oxford and Portland, Oregon, 2005.

Dirjen Perlidungan Hutan dan Pelestarian Alam Departemen Kehutanan RI, Tanam Nasional Siberut: Pengembangan Konservasi Alam Terpadu Rencana Pengelolaan (ICMP) Ringkasan Eksekutif, Padang, Sumbar, Juli 1995.

Farrar, John H. Introduction to Legal Method, third edition, London: Sweet \& Maxwell, 1990.

Friedman, L. The Legal System: A Social Science Perspective, Russel Sage Foundation, New York, tanpa tahun.

Golberg, Stephen B., et. al, Dispute Resolution: Negotiation, Mediation, and Other Process, Second edition, Boston: Little Brown and Company, 1992.

Harsono, Budi. Hukum Agraria Indonesia/Sejarah Pembentukan Undangundang Pokok Agraria, Isi dan Pelaksanaannya, Cet. IX, Jakarta: Djambatan, 2003.

Himpunan Peraturan dibidang Pertanahan dan Perumahan Tahun 2004, Jakarta: Cipta Jaya, 2004.

Hermit, Herman. Cara Memperoleh Sertifikat Tanah Milik, Tanah Negara dan Tanah Pemda/Teori dan Praktik Pendaftaran Tanah di Indonesia, cetakan I, Bandung: Mandar Madju, 2004.

Maleong, Lexy J. Metodologi Penetilian Kualitatif, Bandung: PT Remadja Rosda Karya, 2000. 
Melchert, Norman. The Great Conversation: A Historical Introduction to Philosophy, Fourth edition, Oxford University Press, 2002.

Mertokusumo, Sudikno. A Pitlo, Bab-bab tentang Penemuan Hukum, Cetakan I , Yogyakarta: Citra Aditya Bakti, 1993.

Perlindungan, A.P. Komentar Atas Undang-undang Pokok Agraria, cetakan VIII, Bandung: Mandar Madju, 1998.

Plezer, Karl J. Planters against Peasants, The Agrarian Struggle in East Sumatra 1947-1958, Sengketa Agraria, Pengusaha Perkebunan melawan Petani, terjemahan Bosco Carvallo, Sinar Harapan, 1989.

Rawls, John. A Theory of Justice, revised edition, Oxford University Press, New York, 1999.

Samuel, Geoffrey. Epistemology and Method in Law, England: Ashgate, 2003.

Santosa, Mas Achmad. Demokrasi Pengelolaan Sumberdaya Alam, Jakarta: ICEL, 1999.

Sarjono, Soekanto. Pengantar Ilmu Penulisan Hukum, Jakarta: UI Press, 1988.

Sihombing, B.F. Evolusi Kebijakan Pertanahan dalam Hukum Tanah Indonesia, Cetakan II, Jakarta: Gunung Agung TBK, 2005.

Soerodjo, Irawan. Kepastian Hukum Hak Atas Tanah di Indonesia, Cetakan I, Surabaya: Artaloka, 2003.

Soemitro, Ronny Hanitijo. Metodologi Penulisan Hukum dan Jurimetri, Jakarta: Ghalia Indonesia, 1990.

Sumardjono, Maria SW. Pedoman Pembuatan Usulan Penulisan, Jakarta: Gramedia Pustaka Utama, 1996.

Sutrisno, Hadi. Metodologi Riset, Jilid I, Yogyakarta: Andi, 2000.

The Wordworth. Concise English Dictionary, UK: Wordworth, 2007.

\section{Makalah/Paper}

Saleh, Abdul Aziz. Sustainable Management of Land and Forest Problem in case of Kerinci Seblat National Park, paper, presented at "International Seminar on Legal Complexcity, Natural Resources Management and Social (in) Security in Indonesia", hosted by Universitas Andalas in cooperation with UnPati, UnHas, GaMa, WU, EUR Research Programme, Padang, 6-9 September 1999.

Fauzy, Noer. Jalan Panjang Mendapatkan Keadilan, makalah pada lokakarya "Masyarakat Adat dan Pengurangan Kemiskinan", diselenggarakan oleh Departement Kehakiman dan HAM bekerjasama dengan Asian Development Bank, Jakarta, 25-26 September 2001. 
Jeffery, Y. Campbell. Hutan untuk Rakyat, Masyarakat Adat atau Koperasi? Plural Perspective in the Policy Debate for Community Forestry in Indonesia, paper, presented at "International Seminar on Legal CVomplexcity, Natural Resources Management and Social (in) Security in Indonesia", hosted by Universitas Andalas in co-operation with UnPati, UnHas, GaMa, WU, EUR Research Programme, Padang, 6-9 September 1999.

Santosa, Mas Achmad. Resolusi konflik di bidang Sumber Daya Alam dan Lingkungan Hidup, hosted by Universitas Andalas in co-operation with UnPati, UnHas, GaMa, WU, EUR Research Programme, Padang, 6-9 September 1999.

Syahmunir. Peraturan Menteri Negara/Kepalaq Badan Pertanahan Nasional nomor 5 Tahun 1999 dan Politik Hukum Pertanahan Republik Indonesia, makalah disampaikan pada diskusi tentang sosialisasi "PERMENAG no.5 Tahun 1999 tentang Penyelesaian Masalah Hak Ulayat Masyarakat Hukum Adat", YLBH, Padang, 5 Agustus 1999.

Zulheri, Takdir Rahmadi, Saldi Isra, Kurniawarman. Pola Pemberdayaan Pihak Yang Lemah Dalam Sengketa Pemanfaatan Sumberdaya Alam, kerjasama Pusat Kajian Pilihan Penyelesaian Sengketa Universitas Andalas, Partnership For Economic Growth, dan the United States Agency For International Development, Padang, 2002.

Rahmadi, Takdir. Penyelesaian Sengketa melalui Negosiasi dan Mediasi, makalah, Padang, 1998.

Azheri, Busyra. Penambangan Batubara Pada Tanah Ulayat Di Atas Wilayah Kuasa Pertambangan PT BA UPO di Kecamatan Talawi Sawahlunto, Tesis, Universitas Brawijaya, Malang, 2000. 